medRxiv preprint doi: https://doi.org/10.1101/2020.06.16.20133231; this version posted June 18, 2020. The copyright holder for this preprint (which was not certified by peer review) is the author/funder, who has granted medRxiv a license to display the preprint in perpetuity.

It is made available under a CC-BY-NC-ND 4.0 International license .

Armour et al. Endometriosis and CPP impact

\title{
Endometriosis And Chronic Pelvic Pain Have Similar Impact On Women, But Time To Diagnosis Is Decreasing: An Australian Survey
}

\author{
Mike Armour $^{1,2} *$
}

m.armour@westernsydney.edu.au

Justin Sinclair $^{1}$

J.Sinclair@westernsydney.edu.au

Cecilia $\mathrm{H} \mathrm{M} \mathrm{Ng}{ }^{3}$

cecilia.ng@unsw.edu.au

Mikayla S Hyman ${ }^{4}$

mhyman124@gmail.com

Kenny Lawson ${ }^{2}$

K.Lawson@westernsydney.edu.au

Caroline A Smith ${ }^{1,2}$

caroline.smith@westernsydney.edu.au

Jason Abbott ${ }^{3}$

j.abbott@unsw.edu.au

${ }^{1}$ NICM Health Research Institute, Western Sydney University, Penrith, NSW 2751, Australia

${ }^{2}$ Translational Health Research Institute, Western Sydney University, Penrith, NSW 2751, Australia

${ }^{3}$ School of Women's and Children's Health, University of New South Wales, Sydney, New South

Wales, Australia

${ }^{4}$ Department of Sociology/Anthropology, Middlebury College, Middlebury, VT, United States

* Corresponding Author

NOTE: This preprint reports new research that has not been certified by peer review and should not be used to guide clinical practice. 
medRxiv preprint doi: https://doi.org/10.1101/2020.06.16.20133231; this version posted June 18, 2020. The copyright holder for this preprint (which was not certified by peer review) is the author/funder, who has granted medRxiv a license to display the preprint in perpetuity.

It is made available under a CC-BY-NC-ND 4.0 International license .

Armour et al. Endometriosis and CPP impact

\begin{abstract}
:
Chronic pelvic pain (CPP) affects a significant number of women worldwide. Internationally, people with endometriosis report significant negative impact across many areas of their life. We aimed to use an online survey using the EndoCost tool to determine if there was any difference in the impact of CPP in those with vs. those without a confirmed diagnosis of endometriosis, and if there was any change in diagnostic delay since the introduction of clinical guidelines in 2005. 409 responses were received; 340 with a diagnosis of endometriosis and 69 with no diagnosis. People with CPP, regardless of diagnosis, reported moderate to severe dysmenorrhea and non-cyclical pelvic pain. Dyspareunia was also common. Significant negative impact was reported for social, academic, and sexual/romantic relationships in both cohorts. In the endometriosis cohort there was a mean diagnostic delay of eight years, however there was a reduction in both the diagnostic delay $(\mathrm{p}<0.001)$ and number of doctors seen before diagnosis $(\mathrm{p}<0.001)$ in those presenting more recently. Both endometriosis and CPP have significant negative impact. Whilst there is a decrease in the time to diagnosis, there is an urgent need for improved treatment options and support for women with the disease once the diagnosis is made.
\end{abstract}

\title{
Introduction:
}

Chronic pain in women and girls has been identified as a top five health concern by Australian women ${ }^{1}$ and is identified by a government report as an Australian National Women's Health Priority ${ }^{2}$. There are a variety of causes for chronic pelvic pain (CPP) including endometriosis, adenomyosis, chronic infection, vulvodynia irritable bowel syndrome or bladder pain syndrome. Endometriosis is the most common cause of CPP ${ }^{3}$, accounting for $24-40 \%$ of all CPP diagnoses ${ }^{4,5}$ and has a prevalence rate of around $11 \%$ in 
medRxiv preprint doi: https://doi.org/10.1101/2020.06.16.20133231; this version posted June 18, 2020. The copyright holder for this preprint (which was not certified by peer review) is the author/funder, who has granted medRxiv a license to display the preprint in perpetuity.

It is made available under a CC-BY-NC-ND 4.0 International license .

Armour et al. Endometriosis and CPP impact

Australia ${ }^{6}$. Some people have no demonstrated pathology despite detailed surgical investigation or imaging, leading to a diagnosis of Chronic Pelvic Pain Syndrome (CPPS).

It has been repeatedly demonstrated internationally that endometriosis has a long diagnostic delay ${ }^{7}$, impacts people's health and wellbeing ${ }^{8}$, including social activities ${ }^{9}$, mental and emotional health ${ }^{10,11}$, work/finances ${ }^{9,12}$, and sexual relationships ${ }^{13}$; and those with endometriosis report physical quality of life similar to that of cancer patients ${ }^{9}$. While most research has focused on endometriosis, it is possible that people with non-endometriosis related CPP experience similar issues but possibly with less severe impact ${ }^{14}$, however there is a paucity of research in this area.

The aim of this survey was to determine in an Australian population, with endometriosis or non-endometriosis related CPP, the process of diagnosis, the prevalence of different CPP symptoms, and to explore the management and impact on people's social, sexual/romantic, work, and academic lives.

\section{Methods:}

\section{Questionnaire}

The World Endometriosis Research Foundation (WERF) EndoCost tool consists of validated prospective hospital questionnaires and both retrospective and prospective patient questionnaires ${ }^{15}$. Our study used the 99 item retrospective patient questionnaire, modified to Australian income and ethnicity parameters as per the Australian Bureau of Statistics ${ }^{16}$. The survey was hosted on SurveyMonkey (www.surveymonkey.com), with an estimated 30-45 minute completion time. The cost of illness burden has been previously published ${ }^{12}$, with 
medRxiv preprint doi: https://doi.org/10.1101/2020.06.16.20133231; this version posted June 18, 2020. The copyright holder for this preprint (which was not certified by peer review) is the author/funder, who has granted medRxiv a license to display the preprint in perpetuity.

It is made available under a CC-BY-NC-ND 4.0 International license .

Armour et al. Endometriosis and CPP impact

this paper reporting on items contributing to the WERF Global Study on Women's Health ${ }^{9}$. It focuses on diagnosis, education, work and social wellbeing as well as recent (3 month) prevalence of other pelvic pain symptoms such as dysmenorrhea and dyspareunia.

\section{Recruitment}

Following ethics approval by the Western Sydney University Human Research Ethics Committee, (approval number H12019), the survey link was distributed via the social media platforms (Facebook, Twitter and Instagram) of Endometriosis Australia, EndoActive and Pelvic Pain Foundation of Australia from February 2017 to April 2017, for a total of eight weeks. The total combined reach of these organizations on social media was just over 35,000 followers at the time of survey distribution. Each organization made two social media posts regarding the survey 3-5 weeks apart. Data collection was closed once there had been no new responses for five days. Informed consent was obtained from all participants. Both the participant information sheet and the survey introduction outlined that completion of the survey implied consent. All research complied with the relevant guidelines and regulations outlined in the National Statement on Ethical Conduct in Human Research (2018) ${ }^{17}$.

\section{Study population}

People were eligible to participate in the survey if they were aged 18-45, currently living in Australia and either had a surgically confirmed diagnosis of endometriosis, or if they had CPP from any cause. CPP was defined as pain in the pelvis for at least six months that caused the person to seek medical attention. Those with CPP either had a laparoscopy that did not show evidence of endometriosis or had not undergone a laparoscopy at the time of survey. This study was designed to measure prevalence of symptoms and assess their impact rather than test a hypothesis, therefore no sample size calculation was performed. 


\section{Analyses}

Data were analysed using SPSS v26 (IBM Corporation, Chigago Ill.). Descriptive statistics were presented as means and standard deviations (for normally distributed data), medians and interquartile ranges (for non-normally distributed data), or number and percentages (for categorical data). Inferential statistics for between-group comparisons were performed using a one-way ANOVA, chi-square test or Fishers Exact as appropriate. Correlations between categorical and continuous variables were analysed using Spearman's rank order correlation, and correlations between two continuous variables were analysed using Pearson's Correlation. Statistical significance was set at $\mathrm{p}<0.05$. Missing data were reported and not replaced.

To explore the potential effect of the introduction of the first publication of the European Society of Human Reproduction and Embryology (ESHRE) diagnostic guidelines in $2005^{18}$, the 2013 World Endometriosis Society (WES) diagnostic guidelines and updated ESHRE guidelines in $2013^{19,20}$ we planned to group the analysis on diagnostic delay and number of doctors seen prior to diagnosis into three groups based on the timing of their first presentation to a doctor; presentation prior to 2005, presentation between 2005 and 2012, and presentation from 2013 onwards.

\section{Results}

409 valid responses were received. 340 of these people had endometriosis (83\%) and 69 (17\%) had CPP without a current diagnosis of endometriosis. Table 1 outlines the demographic characteristics of survey participants. The mean age of respondents identifying as being affected by endometriosis was $30.6( \pm 7)$ and CPP was $33.7( \pm 16.3)$ years. The majority of respondents earned between AUD\$510-\$1500 per week, with a little more than 
medRxiv preprint doi: https://doi.org/10.1101/2020.06.16.20133231; this version posted June 18, 2020. The copyright holder for this preprint (which was not certified by peer review) is the author/funder, who has granted medRxiv a license to display the preprint in perpetuity.

It is made available under a CC-BY-NC-ND 4.0 International license .

Armour et al. Endometriosis and CPP impact

half of people across both groups held either university or post-secondary qualifications. In people with endometriosis, $33.7 \%$ reported stage IV disease at their most recent laparoscopy.

\section{(Insert Table 1)}

Symptoms and diagnosis

Table 2 outlines the diagnostic data and symptoms at onset for both cohorts. A Pearson's correlation found a statistically significant, strong negative correlation between the year when medical attention was first sought and the number of years taken to get a diagnosis of endometriosis, $r=-0.71, \mathrm{p}<0.001$. We compared the delay between when medical attention was first sought and found a significant difference in delay for the person who first sought

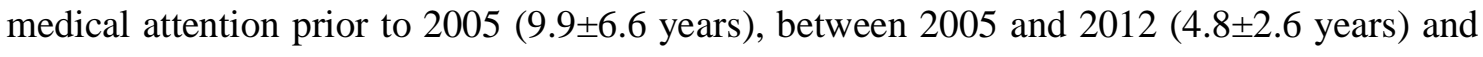
from $2013(1.5 \pm 0.7$ years $)$ onwards $(\mathrm{p}<0.001)$. A Spearman's correlation was performed and found there was a statistically significant negative correlation between the year when medical attention was first sought and the number of doctors seen to get a diagnosis in people with endometriosis, $\mathrm{r}_{\mathrm{s}}=-0.305, \mathrm{p}<0.001$. Similar to the reduction in delay, the number of doctors seen before diagnosis was also reduced significantly after the introduction of the first ESHRE guideline $(\mathrm{p}<0.001)$.

There was a moderate negative correlation between the year symptoms first appeared and the delay in seeking medical attention, $r=-0.39$, $\mathrm{p}<0.001$.

\section{(Insert Table 2)}


medRxiv preprint doi: https://doi.org/10.1101/2020.06.16.20133231; this version posted June 18, 2020. The copyright holder for this preprint (which was not certified by peer review) is the author/funder, who has granted medRxiv a license to display the preprint in perpetuity.

It is made available under a CC-BY-NC-ND 4.0 International license .

People experiencing dysmenorrhea with every period in the previous three months were comparable between the endometriosis (85.9\%) and CPP (87.0\%) cohorts, and dyspareunia was common in both groups, with over two thirds of respondents with endometriosis $(69.1 \%)$ and CPP (66.7\%) reporting experiencing pelvic pain either with or in the 24 hours after intercourse (Table 3).

\section{(Insert Table 3)}

Social, Educational and Work impact.

Substantial negative impact was reported across both cohorts in education, employment and social domains (Table 4).

\section{(Insert Table 4)}

Personal relationships were similarly affected between cohorts, with more than half of respondents indicating problems with their sexual or romantic partners. For those who said pelvic pain impacted their personal relationships around one in six people in either group indicated that this had caused the breakdown of their relationship. The most commonly reported impact for people with endometriosis (35.9\%) was that it affected their friendships. At least one in five people in each cohort indicated that they found it difficult to look after children, and almost a third indicated it caused issues with their family.

Non-cyclical pelvic pain 
medRxiv preprint doi: https://doi.org/10.1101/2020.06.16.20133231; this version posted June 18, 2020. The copyright holder for this preprint (which was not certified by peer review) is the author/funder, who has granted medRxiv a license to display the preprint in perpetuity.

It is made available under a CC-BY-NC-ND 4.0 International license .

Armour et al. Endometriosis and CPP impact

Supplementary Table S1 compares the prevalence, severity and management of non-cyclical pelvic pain between cohorts.

\section{Discussion}

Data from this study demonstrates that people with CPP, irrespective of diagnosis, commonly report moderate to severe pelvic pain symptoms, consistent with recent research on endometriosis ${ }^{21}$. People with endometriosis frequently report symptom onset (most commonly dysmenorrhea and pelvic pain) in their late teens and overall report an eight year diagnostic delay from symptom onset. Nearly three years of this delay is due to the person not presenting to their medical care provider and the remaining 5 years between initial presentation to a doctor and a surgical diagnosis of endometriosis. This is similar to the delay reported in other studies ${ }^{9,22}$ and may, at least be in part, be due to a normalization of the severe dysmenorrhea that is frequently reported in young people with pelvic pain ${ }^{23-25}$. It may also represent commonly held beliefs that even moderate or greater severity menstrual or pelvic pain is a normal part of 'becoming a woman' or 'something you need to put up with' as documented in qualitative studies ${ }^{22,26,27}$. However, our findings indicate that this delay in presentation to a medical professional is reducing over time, with those reporting their symptoms that have started more recently showing a shorter time delay in seeking medical attention. This may be due to an increased awareness of the symptoms of endometriosis and encouragement to seek medical assistance for these through the efforts of advocacy organizations and the recent increased media coverage of endometriosis including events such as Endometriosis Awareness Month. A variety of educational programs, both in person and online, designed to improve awareness of menstruation and endometriosis have also been developed for Australia and elsewhere ${ }^{28-32}$. Most of these resources have been implemented 
medRxiv preprint doi: https://doi.org/10.1101/2020.06.16.20133231; this version posted June 18, 2020. The copyright holder for this preprint (which was not certified by peer review) is the author/funder, who has granted medRxiv a license to display the preprint in perpetuity.

It is made available under a CC-BY-NC-ND 4.0 International license .

Armour et al. Endometriosis and CPP impact

in 2019 and beyond, therefore, given the timing of our survey, it is too soon to see whether these programs may contribute to any further reduction in diagnostic delay.

Similarly, the clinician seeing the person with CPP for the first time may normalize those symptoms ${ }^{22}$ or provide other diagnoses such as irritable bowel syndrome or sexually transmitted infections ${ }^{27,33}$, which can lead to frustration for the patient and further delay in appropriate management that targets their symptoms. Since the introduction of the ESHRE guideline on endometriosis in 2005 , there appears to be a significant reduction in both the number of doctors seen before diagnosis and the time between seeking medical help and a diagnosis of endometriosis. It is unclear at this time if an earlier diagnosis of endometriosis will improve pain and fertility outcomes. However, earlier identification of abnormal menstrual symptoms in early education programs ${ }^{28}$ may allow for an earlier intervention that could change the course of disease and, at least, improve the quality of life of those affected if appropriately managed. This goal is identified in the Australian National Action Plan for Endometriosis ${ }^{34}$ and needs further investigation in future research studies.

Pain and the associated symptom of fatigue is commonly seen in people with endometriosis 21,35 and are significant contributors to both the work and education-related absenteeism and presenteeism seen in our respondents ${ }^{27}$. Fatigue is a common symptom in people with endometriosis and other types of pelvic pain with $39-43 \%$ of respondents reporting that symptom at the onset and all clinicians should ask about this symptom when taking a history of a person presenting with pelvic pain. The fatigue experienced may be debilitating ${ }^{36}$ and there is a strong correlation between pain severity and fatigue ${ }^{37}$, almost certainly explaining why chronic fatigue syndrome is much more common in people with endometriosis than the general population ${ }^{37}$. Educational absenteeism in our survey led to giving up study for 25- 
medRxiv preprint doi: https://doi.org/10.1101/2020.06.16.20133231; this version posted June 18, 2020. The copyright holder for this preprint (which was not certified by peer review) is the author/funder, who has granted medRxiv a license to display the preprint in perpetuity.

It is made available under a CC-BY-NC-ND 4.0 International license .

Armour et al. Endometriosis and CPP impact

$50 \%$ of people. This is notable since academic achievement declines with any absenteeism 38,39. Absenteeism also increases social isolation and decreases engagement with peers. The community ${ }^{40}$ and the consequential cessation of education may substantially limit long-term opportunities for people with endometriosis and CPP.

Previous international surveys ${ }^{8,9}$ and qualitative research ${ }^{22,27}$ have highlighted the impact of endometriosis on social activities and marital/sexual relationships. We also demonstrated that personal relationships, whether friendships or those of a romantic/sexual nature, were negatively impacted by endometriosis and CPP. Reasons for this may include the fatigue experienced reducing social interactions ${ }^{35,37}$ and increased anxiety of experiencing heavy menstrual bleeding, nausea, gastrointestinal and bladder symptoms ${ }^{27}$ in public places when interacting with friends, family or others. Similar to previous work ${ }^{13}$, romantic and sexual relationships were commonly affected in both cohorts, with pain as a direct contributor, but fatigue, nausea, depression, and other co-morbidities also, often, contributing to relationship strain and potential breakdown ${ }^{41}$.

Compared to those with endometriosis people with CPP had symptom onset later, in their early 20s, but with similar presenting symptoms. Previous work also identified a substantial number of people who report CPP symptoms but have not been given any diagnosis ${ }^{42,43}$. Of course, pelvic pain may later be diagnosed as endometriosis ${ }^{21}$ but most importantly, our work confirms that both diagnosed and non-diagnosed CPP causes substantive negative impact on work, education, sexual relationships, family and friendships. It is therefore necessary to identify and have a treatment plan for pelvic pain symptoms, regardless of the current or future diagnosis. 
medRxiv preprint doi: https://doi.org/10.1101/2020.06.16.20133231; this version posted June 18, 2020. The copyright holder for this preprint (which was not certified by peer review) is the author/funder, who has granted medRxiv a license to display the preprint in perpetuity.

It is made available under a CC-BY-NC-ND 4.0 International license .

Armour et al. Endometriosis and CPP impact

There are a number of strengths of this study. Whilst this is the first Australian study for endometriosis and there exist similar estimates from other countries ${ }^{8,44,45}$, there are no previous data on the impact of CPP. The use of the WERF EndoCost tool also allows comparison between datasets generated between different centers. However, there are limitations of this study that must be acknowledged. The overall sample size is small, which may reflect the in-depth nature of the questionnaires, which required up to 45 minutes to complete. Respondents were asked to answer the endometriosis section only if they had a histologically confirmed surgical diagnosis although confirmatory evidence of that was not possible. We recognize that people designated to the CPP cohort may have undiagnosed endometriosis, which is an eventual diagnosis in $33-75 \%{ }^{36,37}$ of this group. Importantly, our study demonstrates similar negative impacts across many domains irrespective of diagnosis. We did not collect data on geographical location of respondents, so it is possible that our sample did not represent potential variations in the access to appropriately specialised health care professionals, work, or educational opportunities. Respondents were predominantly Caucasian, and therefore caution must be heeded in extrapolating these findings to other culturally and linguistically diverse groups. Given the timing of the survey in early 2017, there may be a ceiling effect with respect to diagnostic delay for the cohort that presented to their health care professional after 2013. However, the reported diagnostic delay observed between 2005-2012 is unlikely to be affected by any ceiling effect. Finally, our recruitment was almost solely via advisory and support groups on social media, and people recruited via this method are likely to have more severe symptoms than those recruited in other settings such as tertiary care ${ }^{46}$. So it is possible that our respondents may be biased towards a more severe impact of their symptoms on their lives and may not represent the population of people with endometriosis as a whole. 
medRxiv preprint doi: https://doi.org/10.1101/2020.06.16.20133231; this version posted June 18, 2020. The copyright holder for this preprint (which was not certified by peer review) is the author/funder, who has granted medRxiv a license to display the preprint in perpetuity. It is made available under a CC-BY-NC-ND 4.0 International license .

Armour et al. Endometriosis and CPP impact

\section{Conclusion}

People with CPP, regardless of a diagnosis of endometriosis, experience significant negative impact across a range of domains including education, work, social, and romantic/sexual relationships, which may have long lasting consequences if not appropriately recognised and managed through access to adequate health care resources. Our findings suggest that there has been a significant decrease in diagnostic delay over time, possibly due to improved guidelines and advocacy. However, the diagnostic delay still exists and still carries a significant burden to those suffering CPP. Widespread, evidence based educational programs, recognising the symptom profile of CPP, for both the public and medical providers, are urgently needed to help reduce this delay and implement and provide access to the most appropriate management plan for these people.

\section{Acknowledgements}

Thank you to the organisations that promoted this survey; Endometriosis Australia, EndoActive and the Pelvic Pain Foundation of Australia. Thank you to the World Endometriosis Research Foundation (WERF) for allowing us to use their EndoCost tool and to Lone Hummelshoj who provided valuable guidance on the final manuscript.

\section{Author contributions}

All authors contributed significantly to this work. MA, KL, CS and JA designed the study. MA, KL, JS and MH performed the data collection and statistical analysis. MA and JS drafted the article. JA, CS, CN and KL contributed to critical revisions on the manuscript. All authors reviewed the manuscript and approved the final draft. 
medRxiv preprint doi: https://doi.org/10.1101/2020.06.16.20133231; this version posted June 18, 2020. The copyright holder for this preprint (which was not certified by peer review) is the author/funder, who has granted medRxiv a license to display the preprint in perpetuity.

It is made available under a CC-BY-NC-ND 4.0 International license .

Armour et al. Endometriosis and CPP impact

\section{Competing interests}

MA,JS, CS: As a medical research institute, NICM Health Research Institute receives research grants and donations from foundations, universities, government agencies and industry. Sponsors and donors provide untied and tied funding for work to advance the vision and mission of the Institute. This study was not specifically supported by donor or sponsor funding to NICM. MA is a member of the clinical advisory board for Endometriosis Australia.

JA: Medical Director, Endometriosis Australia (NFP)

KL: None known.

CN: None known.

MH: None known.

\section{Data availability}

The datasets generated during and/or analysed during the current study are available from the corresponding author on reasonable request. 
medRxiv preprint doi: https://doi.org/10.1101/2020.06.16.20133231; this version posted June 18, 2020. The copyright holder for this preprint (which was not certified by peer review) is the author/funder, who has granted medRxiv a license to display the preprint in perpetuity. It is made available under a CC-BY-NC-ND 4.0 International license .

Armour et al. Endometriosis and CPP impact

\section{References.}

1 Jean Hailes for Women's Health. Women's Health Survey 2016: Understanding health information needs and health behaviours of women in Australia, $<$ https://assets.jeanhailes.org.au/Research/Womens-Health-Survey-Report2016.pdf> (2016).

2 Australian Government Department of Health and Aging. National Women's Health Policy. (2010).

3 Hickey, M., Ballard, K. \& Farquhar, C. Endometriosis. BMJ 348, g1752, doi:10.1136/bmj.g1752 (2014).

$4 \quad$ Whitaker, L. H. et al. An Exploratory Study into Objective and Reported Characteristics of Neuropathic Pain in Women with Chronic Pelvic Pain. PLoS One 11, e0151950, doi:10.1371/journal.pone.0151950 (2016).

5 Mowers, E. L. et al. Prevalence of Endometriosis During Abdominal or Laparoscopic Hysterectomy for Chronic Pelvic Pain. Obstet Gynecol 127, 1045-1053, doi:10.1097/AOG.0000000000001422 (2016).

6 Australian Institute of Health and Welfare. Endometriosis in Australia: prevalence and hospitalisations. (AlHW, Canberra, 2019).

7 Agarwal, S. K. et al. Clinical diagnosis of endometriosis: a call to action. Am J Obstet Gynecol 220, 354 e351-354 e312, doi:10.1016/j.ajog.2018.12.039 (2019).

8 De Graaff, A. A. et al. The significant effect of endometriosis on physical, mental and social wellbeing: results from an international cross-sectional survey. Hum Reprod 28, 2677-2685, doi:10.1093/humrep/det284 (2013).

9 Nnoaham, K. E. et al. Impact of endometriosis on quality of life and work productivity: a multicenter study across ten countries. Fertil Steril 96, 366-373 e368, doi:10.1016/j.fertnstert.2011.05.090 (2011).

10 Sepulcri Rde, P. \& do Amaral, V. F. Depressive symptoms, anxiety, and quality of life in women with pelvic endometriosis. Eur J Obstet Gynecol Reprod Biol 142, 53-56, doi:10.1016/j.ejogrb.2008.09.003 (2009).

11 Osorio, F. L., Carvalho, A. C., Donadon, M. F., Moreno, A. L. \& Polli-Neto, O. Chronic pelvic pain, psychiatric disorders and early emotional traumas: Results of a cross sectional case-control study. World J Psychiatry 6, 339-344, doi:10.5498/wjp.v6.i3.339 (2016).

12 Armour, M., Lawson, K., Wood, A., Smith, C. A. \& Abbott, J. The cost of illness and economic burden of endometriosis and chronic pelvic pain in Australia: A national online survey. PLoS One 14, e0223316, doi:10.1371/journal.pone.0223316 (2019).

13 Pluchino, N. et al. Sexual function in endometriosis patients and their partners: effect of the disease and consequences of treatment. Hum Reprod Update, doi:10.1093/humupd/dmw031 (2016).

14 Winkel, C. A. Modeling of medical and surgical treatment costs of chronic pelvic pain: new paradigms for making clinical decisions. Am J Manag Care 5, S276-290 (1999).

15 Simoens, S. et al. Endometriosis cost assessment (the EndoCost study): a cost-ofillness study protocol. Gynecol Obstet Invest 71, 170-176, doi:10.1159/000316055 (2011). 
medRxiv preprint doi: https://doi.org/10.1101/2020.06.16.20133231; this version posted June 18, 2020. The copyright holder for this preprint (which was not certified by peer review) is the author/funder, who has granted medRxiv a license to display the preprint in perpetuity. It is made available under a CC-BY-NC-ND 4.0 International license .

Armour et al. Endometriosis and CPP impact

16 Australian Bureau of Statistics. 1249.0 - Australian Standard Classification of Cultural and Ethnic Groups (ASCCEG), <http://www.abs.gov.au/ausstats/abs@.nsf/mf/1249.0> (2016).

17 The National Health and Medical Research Council. National Statement on Ethical Conduct in Human Research 2007 (Updated 2018), $<$ www.nhmrc.gov.au/guidelines/publications/e72> (2018).

18 Kennedy, S. et al. ESHRE guideline for the diagnosis and treatment of endometriosis. Hum Reprod 20, 2698-2704, doi:10.1093/humrep/dei135 (2005).

19 Johnson, N. P., Hummelshoj, L. \& World Endometriosis Society Montpellier, C. Consensus on current management of endometriosis. Hum Reprod 28, 1552-1568, doi:10.1093/humrep/det050 (2013).

20 Dunselman, G. A. J. et al. ESHRE guideline: management of women with endometriosis †. Human Reproduction 29, 400-412, doi:10.1093/humrep/det457 (2014).

21 Markham, R., Luscombe, G. M., Manconi, F. \& Fraser, I. S. A detailed profile of pain in severe endometriosis. Journal of endometriosis and pelvic pain disorders 11, 85-94, doi:10.1177/2284026519838948 (2019).

22 Moradi, M., Parker, M., Sneddon, A., Lopez, V. \& Ellwood, D. Impact of endometriosis on women's lives: a qualitative study. BMC women's health 14, 123, doi:10.1186/1472-6874-14-123 (2014).

$23 \mathrm{Li}, \mathrm{A}$. D. et al. Unmet Needs and Experiences of Adolescent Girls with Heavy Menstrual Bleeding and Dysmenorrhea: A Qualitative Study. J Pediatr Adolesc Gynecol, doi:10.1016/j.jpag.2019.11.007 (2019).

24 Banikarim, C., Chacko, M. R. \& Kelder, S. H. Prevalence and impact of dysmenorrhea on Hispanic female adolescents. Arch Pediatr Adolesc Med 154, 1226-1229 (2000).

25 Wong, L. P. Attitudes towards dysmenorrhoea, impact and treatment seeking among adolescent girls: A rural school-based survey. Australian Journal of Rural Health 19, 218-223 (2011).

26 Armour, M., Dahlen, H. G. \& Smith, C. A. More Than Needles: The Importance of Explanations and Self-Care Advice in Treating Primary Dysmenorrhea with Acupuncture. Evid Based Complement Alternat Med 2016, 3467067, doi:10.1155/2016/3467067 (2016).

27 Young, K., Fisher, J. \& Kirkman, M. Women's experiences of endometriosis: a systematic review and synthesis of qualitative research. J Fam Plann Reprod Health Care 41, 225-234, doi:10.1136/jfprhc-2013-100853 (2015).

28 Bush, D., Brick, E., East, M. C. \& Johnson, N. Endometriosis education in schools: A New Zealand model examining the impact of an education program in schools on early recognition of symptoms suggesting endometriosis. Aust N Z J Obstet Gynaecol, doi:10.1111/ajo.12614 (2017).

29 Lawton, T. Period Talk, <https://periodtalk.com.au> (2019).

30 Pelvic Pain Foundation of Australia. PEPP Talk, $<$ https://www.pelvicpain.org.au/schools-ppep-program/> (2020).

31 QENDO. Schools Program, <https://www.qendo.org.au/schools-program> (2020).

32 Endometriosis Australia. Webinars, $<$ https://www.endometriosisaustralia.org/webinars> (2020).

33 Seear, K. The etiquette of endometriosis: stigmatisation, menstrual concealment and the diagnostic delay. Social science \& medicine 69, 1220-1227 (2009). 
medRxiv preprint doi: https://doi.org/10.1101/2020.06.16.20133231; this version posted June 18, 2020. The copyright holder for this preprint (which was not certified by peer review) is the author/funder, who has granted medRxiv a license to display the preprint in perpetuity. It is made available under a CC-BY-NC-ND 4.0 International license .

Armour et al. Endometriosis and CPP impact

34 Australian Government Department of Health. National Action Plan for Endometriosis, <http://www.health.gov.au/internet/main/publishing.nsf/Content/endometriosis > (2018).

35 Sinaii, N., Cleary, S. D., Ballweg, M., Nieman, L. K. \& Stratton, P. High rates of autoimmune and endocrine disorders, fibromyalgia, chronic fatigue syndrome and atopic diseases among women with endometriosis: a survey analysis. Human reproduction 17, 2715-2724 (2002).

36 Lemaire, G. S. More than just menstrual cramps: symptoms and uncertainty among women with endometriosis. Journal of Obstetric, Gynecologic \& Neonatal Nursing 33, 71-79 (2004).

37 Ramin-Wright, A. et al. Fatigue - a symptom in endometriosis. Human Reproduction 33, 1459-1465, doi:10.1093/humrep/dey115 (2018).

38 Gottfried, M. A. Evaluating the Relationship Between Student Attendance and Achievement in Urban Elementary and Middle Schools:An Instrumental Variables Approach. American Educational Research Journal 47, 434-465, doi:10.3102/0002831209350494 (2010).

39 Hancock, K. J., Shepherd, C. C. J., Lawrence, D. \& Zubrick, S. R. Student attendance and educational outcomes: Every day counts, $<$ www.telethonkids.org.au/globalassets/media/documents/research-topics/studentattendance-and-educational-outcomes-2015.pdf> (2013).

40 AITSL. Attendance Matters. Australian Institute for Teaching and School Leadership, $<$ https://www.aitsl.edu.au/docs/default-source/research-evidence/spotlight/11319aitsl spotlight attendance web-fa.pdf?sfvrsn=5bb0ff3c 6> (2019).

41 Culley, L. et al. A qualitative study of the impact of endometriosis on male partners. Human Reproduction 32, 1667-1673, doi:10.1093/humrep/dex221 (2017).

42 Pitts, M. K., Ferris, J. A., Smith, A. M., Shelley, J. M. \& Richters, J. Prevalence and correlates of three types of pelvic pain in a nationally representative sample of Australian women. Med J Aust 189, 138-143 (2008).

43 Parker, M. A., Sneddon, A. E. \& Arbon, P. The menstrual disorder of teenagers (MDOT) study: determining typical menstrual patterns and menstrual disturbance in a large population-based study of Australian teenagers. BJOG 117, 185-192, doi:10.1111/j.1471-0528.2009.02407.x (2010).

$44 \quad K$ Kein, S. et al. What is the societal burden of endometriosis-associated symptoms? a prospective Belgian study. Reprod Biomed Online 28, 116-124, doi:10.1016/j.rbmo.2013.09.020 (2014).

45 Simoens, S. et al. The burden of endometriosis: costs and quality of life of women with endometriosis and treated in referral centres. Hum Reprod 27, 1292-1299, doi:10.1093/humrep/des073 (2012).

46 De Graaff, A. A. et al. Quality of life outcomes in women with endometriosis are highly influenced by recruitment strategies. Hum Reprod 30, 1331-1341, doi:10.1093/humrep/dev084 (2015). 
medRxiv preprint doi: https://doi.org/10.1101/2020.06.16.20133231; this version posted June 18, 2020. The copyright holder for this preprint (which was not certified by peer review) is the author/funder, who has granted medRxiv a license to display the preprint in perpetuity.

It is made available under a CC-BY-NC-ND 4.0 International license .

Armour et al. Endometriosis and CPP impact

Table 1: Demographics

\begin{tabular}{|c|c|c|}
\hline & $\begin{array}{l}\text { Endometriosis } \\
(n=340)\end{array}$ & Chronic Pelvic Pain ( $n=69$ ) \\
\hline & Mean (SD) & Mean (SD) \\
\hline Age $(y)$ & $30.6(7.0)$ & $33.7(16.3)$ \\
\hline \multicolumn{3}{|l|}{ Ethnicity, $\mathrm{n}(\%)$} \\
\hline Caucasian & $312(91.8 \%)$ & $64(92.8 \%)$ \\
\hline Asian & $5(1.5 \%)$ & $2(2.9 \%)$ \\
\hline Aboriginal/TSI & $5(1.5 \%)$ & $1(1.4 \%)$ \\
\hline Polynesian & $0(0 \%)$ & $0(0 \%)$ \\
\hline Maori & $0(0 \%)$ & $0(0 \%)$ \\
\hline Other & $17(5 \%)$ & $2(2.8 \%)$ \\
\hline Blank & $1(0.3 \%)$ & $0(0 \%)$ \\
\hline \multicolumn{3}{|l|}{ Relationship status, $\mathrm{n}(\%)$} \\
\hline Single & $69(20.3 \%)$ & $14(20.3 \%)$ \\
\hline Married/Defacto & $211(62.1 \%)$ & $50(72.5 \%)$ \\
\hline In a relationship but not living with partner & $49(14.4 \%)$ & $4(5.8)$ \\
\hline Divorced/Separated & $9(2.6 \%)$ & $0(0 \%)$ \\
\hline Widowed & $0(0 \%)$ & $1(1.4 \%)$ \\
\hline Blank & $2(0.6 \%)$ & $0(0 \%)$ \\
\hline \multicolumn{3}{|l|}{ Occupation, $\mathrm{n}(\%)$} \\
\hline Self-employed & $23(6.8 \%)$ & $4(5.8 \%)$ \\
\hline Employed & $236(69.4 \%)$ & $47(68.1 \%)$ \\
\hline Going to school or University & $70(20.6 \%)$ & $15(21.7 \%)$ \\
\hline Home duties/ caring for children and family & $43(12.6 \%)$ & $10(14.5 \%)$ \\
\hline Doing voluntary work & $18(5.3 \%)$ & $2(2.9 \%)$ \\
\hline Unable to work due to pelvic pain symptoms & $23(6.8 \%)$ & $7(10.1 \%)$ \\
\hline Unable to work for other reasons & $5(1.5 \%)$ & $2(2.9 \%)$ \\
\hline \multicolumn{3}{|c|}{ Level of education, $\mathrm{n}(\%)$} \\
\hline Primary School & $0(0 \%)$ & $0(0 \%)$ \\
\hline Lower secondary & $24(7 \%)$ & $2(2.9 \%)$ \\
\hline Upper secondary & $47(13.8 \%)$ & $6(8.7 \%)$ \\
\hline Post-secondary (TAFE) & $91(26.8 \%)$ & $22(31.9 \%)$ \\
\hline University & $123(36.2 \%)$ & $25(36.2 \%)$ \\
\hline Post graduate & $55(16.2 \%)$ & $14(20.3 \%)$ \\
\hline Blank & $0(0 \%)$ & $0(0 \%)$ \\
\hline \multicolumn{3}{|l|}{ Currently have children, $\mathrm{n}(\%)$} \\
\hline Yes & $97(28.5 \%)$ & $23(33.3 \%)$ \\
\hline No & $242(71.2 \%)$ & $46(66.7 \%)$ \\
\hline Blank & $1(>1 \%)$ & $0(0 \%)$ \\
\hline \multicolumn{3}{|c|}{ Endometriosis stage at most recent laparoscopy, $\mathrm{n}(\%)$} \\
\hline Stage 1 & $14(4.1 \%)$ & \\
\hline Stage 2 & $51(15 \%)$ & \\
\hline Stage 3 & $75(22.1 \%)$ & \\
\hline Stage 4 & $115(33.7 \%)$ & \\
\hline Can't remember & $57(16.8 \%)$ & \\
\hline Blank & $28(8.3 \%)$ & \\
\hline
\end{tabular}


medRxiv preprint doi: https://doi.org/10.1101/2020.06.16.20133231; this version posted June 18, 2020. The copyright holder for this preprint (which was not certified by peer review) is the author/funder, who has granted medRxiv a license to display the preprint in perpetuity.

It is made available under a CC-BY-NC-ND 4.0 International license .

Armour et al. Endometriosis and CPP impact

Table 2: Symptoms and diagnosis

\begin{tabular}{|c|c|c|c|}
\hline & $\begin{array}{l}\text { Endometriosis } \\
\text { ( } n=340) \\
\text { Mean (SD) }\end{array}$ & $\begin{array}{l}\text { Chronic Pelvic Pain } \\
\text { ( } n=69) \\
\text { Mean (SD) }\end{array}$ & P value \\
\hline Age when symptoms first appeared & $18(6)$ & $21.9(8.6)$ & $<0.001^{*}$ \\
\hline Time between symptom onset and first doctors visit (years) & $2.9(4.4)$ & $1.8(3.4)$ & 0.07 \\
\hline Time between doctors visit and diagnosis of endometriosis (years) & $4.9(5.7)$ & $\mathrm{N} / \mathrm{A}$ & $\mathrm{N} / \mathrm{A}$ \\
\hline Number of Doctors seen before diagnosis of endometriosis & $5(4)$ & $\mathrm{N} / \mathrm{A}$ & $\mathrm{N} / \mathrm{A}$ \\
\hline \multicolumn{4}{|l|}{ Number of doctors seen by year of first presentation } \\
\hline Prior to 2005 & $7.3(7.0)$ & $\mathrm{N} / \mathrm{A}$ & $\mathrm{N} / \mathrm{A}$ \\
\hline Between 2005-2012 & $4.3(3.2)$ & $\mathrm{N} / \mathrm{A}$ & $\mathrm{N} / \mathrm{A}$ \\
\hline 2013 onwards & $3.9(2.6)$ & $\mathrm{N} / \mathrm{A}$ & $\mathrm{N} / \mathrm{A}$ \\
\hline \multicolumn{4}{|l|}{ Time between year of first presentation and diagnosis } \\
\hline First sought medical attention before 2005 & $9.9(6.6)$ & $\mathrm{N} / \mathrm{A}$ & $\mathrm{N} / \mathrm{A}$ \\
\hline First sought medical attention between 2005-2012 & $4.8(2.6)$ & $\mathrm{N} / \mathrm{A}$ & $\mathrm{N} / \mathrm{A}$ \\
\hline First sought medical attention after 2013 & $1.5(0.7)$ & $\mathrm{N} / \mathrm{A}$ & $\mathrm{N} / \mathrm{A}$ \\
\hline \multicolumn{4}{|l|}{ Symptoms at onset, $\mathrm{n}(\%)$} \\
\hline Severe Dysmenorrhea & $260(89.4 \%)$ & $57(82.6 \%)$ & \multirow[t]{7}{*}{0.66} \\
\hline Deep Dyspareunia & $84(32.3 \%)$ & $27(39.1 \%)$ & \\
\hline Pelvic Pain & $229(78.7 \%)$ & $51(73.9 \%)$ & \\
\hline Ovulation pain & $136(46.7 \%)$ & $29(42 \%)$ & \\
\hline $\begin{array}{r}\text { Cyclical or peri-menstrual symptoms (e.g. bowel or bladder associated) } \\
\text { with or without abnormal bleeding }\end{array}$ & $111(38.1 \%)$ & $33(47.8 \%)$ & \\
\hline Infertility & $22(7.6 \%)$ & $6(8.7 \%)$ & \\
\hline Chronic Fatigue & $113(38.8 \%)$ & $25(36.2 \%)$ & \\
\hline Blank & $25(7.4 \%)$ & $0(0 \%)$ & \\
\hline
\end{tabular}

*Represents significance $(p<0.001)$ 
medRxiv preprint doi: https://doi.org/10.1101/2020.06.16.20133231; this version posted June 18, 2020. The copyright holder for this preprint (which was not certified by peer review) is the author/funder, who has granted medRxiv a license to display the preprint in perpetuity.

It is made available under a CC-BY-NC-ND 4.0 International license .

Armour et al. Endometriosis and CPP impact

Table 3: Description of menstrual symptoms and sexual intercourse

\begin{tabular}{|c|c|c|c|}
\hline & $\begin{array}{l}\text { Endometriosis } \\
(n=340)\end{array}$ & $\begin{array}{l}\text { Chronic Pelvic Pain } \\
(n=69)\end{array}$ & $P$ value \\
\hline \multicolumn{4}{|l|}{$\begin{array}{l}\text { Pelvic Pain with periods in last } \\
\text { three months, } n(\%)\end{array}$} \\
\hline Yes & $292(85.9 \%)$ & $60(87.0 \%)$ & \multirow[t]{3}{*}{0.92} \\
\hline No & $46(13.5 \%)$ & $7(10.1 \%)$ & \\
\hline Blank & $2(0.6 \%)$ & $2(2.9 \%)$ & \\
\hline \multicolumn{3}{|l|}{ Frequency of pain, $n(\%)$} & \multirow[t]{5}{*}{0.42} \\
\hline Occasionally & $9(3.1 \%)$ & $2(3.3 \%)$ & \\
\hline Often & $27(9.2 \%)$ & $9(15.0 \%)$ & \\
\hline Always & $247(84.6 \%)$ & $48(80.0 \%)$ & \\
\hline Blank & $9(3.1 \%)$ & $1(1.7 \%)$ & \\
\hline $\begin{array}{l}\text { Severity of period pain } \\
\text { (average), median (IQR) }\end{array}$ & $7(6-8)$ & $7(6-8)$ & 0.57 \\
\hline $\begin{array}{l}\text { Severity of period pain } \\
\text { (worse), median (IQR) }\end{array}$ & $8(8-10)$ & $8.5(8-9)$ & 0.91 \\
\hline \multicolumn{3}{|l|}{ Use of painkillers, $n(\%)$} & \multirow[t]{3}{*}{$<0.001^{*}$} \\
\hline Uses Prescription & $181(62.0 \%)$ & $16(23.2 \%)$ & \\
\hline Uses OTC & $57(19.5 \%)$ & $46(66.7 \%)$ & \\
\hline \multicolumn{3}{|l|}{ Affected daily living, $n$ (\%) } & \multirow[t]{6}{*}{0.85} \\
\hline Never & $16(5.5 \%)$ & $5(8.3 \%)$ & \\
\hline Occasionally & $81(27.7 \%)$ & $15(25.0 \%)$ & \\
\hline Often & $100(34.2 \%)$ & $21(35.0 \%)$ & \\
\hline Always & $85(29.1 \%)$ & $18(30 \%)$ & \\
\hline Blank & $7(2.4 \%)$ & $1(1.7 \%)$ & \\
\hline \multicolumn{3}{|l|}{$\begin{array}{l}\text { Pelvic Pain with intercourse, } n \\
(\%)\end{array}$} & \multirow[t]{4}{*}{1.00} \\
\hline Yes & $235(69.1 \%)$ & $46(66.7 \%)$ & \\
\hline No & $30(8.8 \%)$ & $19(27.5 \%)$ & \\
\hline Blank/Other & $55(16.2 \%)$ & $4(5.8 \%)$ & \\
\hline \multicolumn{3}{|l|}{$\begin{array}{l}\text { Frequency of pelvic pain after } \\
\text { intercourse, } n(\%)\end{array}$} & \multirow[t]{6}{*}{0.22} \\
\hline Occasionally & $37(15.7 \%)$ & $12(26.1 \%)$ & \\
\hline Often & $38(16.2 \%)$ & $6(13.0 \%)$ & \\
\hline Usually & $74(31.5 \%)$ & $15(32.6 \%)$ & \\
\hline Always & $86(36.6 \%)$ & $11(23.9 \%)$ & \\
\hline Blank & $0(0 \%)$ & $2(4.3 \%)$ & \\
\hline \multicolumn{3}{|l|}{ Interrupt intercourse, n (\%) } & \multirow[t]{4}{*}{0.94} \\
\hline Yes & $193(82.1 \%)$ & $38(82.6 \%)$ & \\
\hline No & $42(17.9 \%)$ & $6(13.0 \%)$ & \\
\hline Blank & $0(0 \%)$ & $2(4.3 \%)$ & \\
\hline \multicolumn{3}{|l|}{ Avoid intercourse, $n(\%)$} & \multirow[t]{4}{*}{0.89} \\
\hline Yes & $209(88.9 \%)$ & $39(84.8 \%)$ & \\
\hline No & $26(11.1 \%)$ & $5(10.9 \%)$ & \\
\hline Blank & $0(0 \%)$ & $2(4.3 \%)$ & \\
\hline $\begin{array}{l}\text { Pain during intercourse, } \\
\text { median (IQR) }\end{array}$ & $6(4-7)$ & $5(4-8)$ & 0.91 \\
\hline Pain $24 \mathrm{~h}$ after intercourse, & $6(6-6)$ & $6(4-7)$ & 0.74 \\
\hline
\end{tabular}


medRxiv preprint doi: https://doi.org/10.1101/2020.06.16.20133231; this version posted June 18, 2020. The copyright holder for this preprint (which was not certified by peer review) is the author/funder, who has granted medRxiv a license to display the preprint in perpetuity.

It is made available under a CC-BY-NC-ND 4.0 International license .

Armour et al. Endometriosis and CPP impact

\begin{tabular}{|l|l|l|l|}
\hline median (IQR) & & & \\
\hline
\end{tabular}

*Represents significance $(p<0.001)$

Table 4: Social, Educational and Work impact

\begin{tabular}{|c|c|c|}
\hline & $\begin{array}{l}\text { Endometriosis } \\
(\mathrm{n}=340)\end{array}$ & $\begin{array}{l}\text { Chronic Pelvic } \\
\text { Pain ( } \mathrm{n}=69)\end{array}$ \\
\hline \multicolumn{3}{|l|}{ Have you ever lost time to education due to your chronic pelvic pain? $\mathrm{n}(\%)$} \\
\hline Yes & $197(57.9 \%)$ & $29(42.0 \%)$ \\
\hline No & $57(16.8 \%)$ & $26(37.7 \%)$ \\
\hline Blank, $n(\%)$ & $86(25.3 \%)$ & $14(20.3 \%)$ \\
\hline \multicolumn{3}{|l|}{ How did it effect your education (please select all that apply)? $n(\%)$} \\
\hline Gave up studies & $47(23.9 \%)$ & $13(44.8 \%)$ \\
\hline Changed studies & $17(8.6 \%)$ & $4(13.8 \%)$ \\
\hline Delayed exams & $114(57.9 \%)$ & $15(51.7 \%)$ \\
\hline Other & $64(32.5 \%)$ & $3(10.3 \%)$ \\
\hline Blank & $6(3.0 \%)$ & $3(10.3 \%)$ \\
\hline $\begin{array}{l}\text { Average number of days lost per month when you were studying due to your } \\
\text { pelvic pain, mean }(S D)\end{array}$ & $6.5(7.1)$ & $5.4(5.0)$ \\
\hline \multicolumn{3}{|l|}{ Has chronic pelvic pain affected your job? $\mathrm{n}(\%)$} \\
\hline Yes & 199 (58.5\%) & $35(50.7 \%)$ \\
\hline No & $52(15.3 \%)$ & $18(26.1 \%)$ \\
\hline Blank & $89(26.2 \%)$ & $16(23.2 \%)$ \\
\hline \multicolumn{3}{|l|}{ If yes, how did it affect your job (please select all that apply)? $n(\%)$} \\
\hline Lost job & $30(15.1 \%)$ & $3(8.6 \%)$ \\
\hline Changed job & $25(12.6 \%)$ & $2(5.7 \%)$ \\
\hline Reduced hours & $108(54.3 \%)$ & $22(62.9 \%)$ \\
\hline Other & $100(50.3 \%)$ & $17(48.6 \%)$ \\
\hline Blank & $2(1.0 \%)$ & $1(2.9 \%)$ \\
\hline $\begin{array}{l}\text { Average number of days per month you had to take off work due to your chronic } \\
\text { pelvic pain? median (IQR) }\end{array}$ & $4(2-8)$ & $3.5(2-6.75)$ \\
\hline \multicolumn{3}{|l|}{$\begin{array}{l}\text { Have you been scared to tell your employer that you have chronic pelvic pain } \\
\text { because you feared that it might affect your prospects? } n(\%)\end{array}$} \\
\hline Yes & $171(50.3 \%)$ & $36(52.2 \%)$ \\
\hline No & $67(19.7 \%)$ & $13(18.8 \%)$ \\
\hline Blank & $102(30.0 \%)$ & $20(29.0 \%)$ \\
\hline \multicolumn{3}{|l|}{$\begin{array}{l}\text { Has chronic pelvic pain ever affected your personal relationships in a negative } \\
\text { way? } n(\%)\end{array}$} \\
\hline Yes & $202(59.4 \%)$ & $43(62.3 \%)$ \\
\hline No & $43(12.6 \%)$ & $9(13.0 \%)$ \\
\hline Blank & $95(27.9 \%)$ & $17(24.6 \%)$ \\
\hline \multicolumn{3}{|c|}{\begin{tabular}{l|l} 
If yes, how did it affect your personal relationships? (please select all that apply), $n$ & \\
$(\%)$ &
\end{tabular}} \\
\hline Caused significant problems with partner & $120(59.4 \%)$ & $27(62.8 \%)$ \\
\hline Created problems with family & $54(26.7 \%)$ & $13(30.2 \%)$ \\
\hline Caused a relationship to split & $31(15.3 \%)$ & $6(14.0 \%)$ \\
\hline Difficult to look after children & $45(22.3 \%)$ & $11(25.6 \%)$ \\
\hline Affected friendships & $122(60.4 \%)$ & $20(46.5 \%)$ \\
\hline
\end{tabular}


medRxiv preprint doi: https://doi.org/10.1101/2020.06.16.20133231; this version posted June 18, 2020. The copyright holder for this preprint (which was not certified by peer review) is the author/funder, who has granted medRxiv a license to display the preprint in perpetuity.

It is made available under a CC-BY-NC-ND 4.0 International license.

Armour et al. Endometriosis and CPP impact

Other $70(34.7 \%) \quad 14(32.6 \%)$

Blank $5(2.5 \%) \quad 1(2.3 \%)$ 